\title{
A Māori reflection on Spinoza's primordial
}

Māori philosophy is at an exciting point as it looks to other sources for inspiration. In this paper, I refer to some key Māori concepts and terms I have worked with in the past and bring them into discussion with Spinoza's notion of primordial substance in mind. Some Māori terms such as ira (the manifestation and persistence of a thing), whakaaro (indebtedness to a primordial substance) and Papatūānuku (primordial substance) are relevant here.

\section{Approaches to cross-cultural philosophising-a foreword}

There are ethical issues to consider before leaping into conversation with a Western philosopher. Firstly, there is something to be said for keeping Western philosophers at a distance, thereby prioritising the discussion as a Māori one. However, it is debatable whether simply bypassing Western theories is sustainable given their ongoing presence in academic contexts. Further, there is something a bit subversive-or at least playful-in working with a ground of thought that comes from the West, but which is largely accepted in Māori scholarship as colonising. In this paper I pursue the latter precisely because working playfully with difficult thinkers from other cultural philosophies may be useful for Māori. Whether we strictly follow the ideas of the Western writer, or use them as a springboard for some of our own thinking is also important to consider (Mika, 2013: 23). Do we stand in service to the ideas of others, or is there a more nuanced relationship at play between Western and Māori thinkers?

The position I argue is that staying within the conceptual and material grounds of existence is an important existential and ontological ethic for the Indigenous self (Mika, 2017: 13), no less than the scholar. In other words, we need to stay firmly within the generative plane of existence that our first ancestral entities provide. The point of this article is to negotiate both styles as a Māori philosopher who wishes to attend to the immanence of those primordial entities, whilst acknowledging that much good can come from 'throwing oneself outward' towards divergent scholars. Spinoza is a renowned philosopher in Western traditions who nevertheless resonates with Māori thought at critical points, while diverging at others. Coinciding with a Māori perspective, he can be seen to examine the phenomenon of existing within the substance of the All whilst thinking it. 
As such, I propose to carefully engage with him in a way that reflects the reality of Māori cross-cultural discussion (Mika, 2014b: 24) - not necessarily directed by or in full commitment to him, but in respectful dialogue with him. Like Spinoza, I advocate that one can think something and abide within the All, but indicate that there are key points where Māori-either through the subtlety of the Māori language or simply through a difference in concepts-diverge from Spinoza. Hence, there is a mercuriality involved in engaging with Spinoza and a certain volatility for me as a Māori philosopher because, although he may be more sympathetic than, say, many of the classic Greek thinkers, I still have to contend with him as having particular boundaries that do not correspond with my own. He resonates with the early German Romantic poet and philosopher Novalis, for instance, because they both propose that divinity resides within things in the world (Beiser, 2002: 419). As in my thinking with Novalis, though, in my Spinoza-Māori encounter I don't set out just to give comparisons as such between Māori thought and Spinoza's, but to also be productive in my development of Māori notions of the primordial.

\section{Spinoza and Māori primordiality}

For Māori, philosophy starts frequently with acknowledging the ground of the All-what Spinoza calls "God" or "nature". Spinoza clearly thought a rational approach to this foundational substance was of such importance that he made some enemies among his own, with inflammatory comments such as:

[...] he, who seeks for the true causes of miracles, and endeavours, like a scholar, to comprehend the things in nature and not, like a fool, to wonder at them, is everywhere regarded and proclaimed as a heretic and an impious man by those whom the multitude reverence as interpreters of nature and the gods. (1894: 69)

Spinoza treads a difficult line between establishing the apparent irrationalism of being within the All on the one hand, and the reason associated with coming to know this fact on the other. But in some respects, use of terminology is extremely important here; Spinoza does not ascribe "irrationality" to immanence, but to an inability to construct knowledge on the basis of affect. Distance from the worldwhich may result in knowledge-is not possible because we all relate through primordial substance. But his insistence that the All is immanent puts him at odds with many of his contemporaries. Proposing something other than the dominant discourse is also a poignant issue for the Māori scholar. By this, I don't simply mean that it is a fraught issue to be proposing something counter to what the West declares, but also against what Māori commonly declare. Philosophy is especially inclined to critique dominant ways of talking about things, and although it sits quietly in the backdrop of Māori academia, it nevertheless arises as a problem for empirical work-for example, where scientific thinking, broadly conceived, keeps demanding our philosophical attention. Thus, the aim of Māori philosophy is to ruffle established ways of talking about things. Alongside others' ideas, the self is disturbed in that process, because Māori metaphysics is so bound up with the presence of Western thought (Mika, 2017: 13). This thinking about the primordial is uncomfortable for most of us because it challenges how we represent things. 
So much for the antagonism that any of us might face in relation to fundamental propositions or unpopular first principles, but what of God itself? Māori, of course, have a number of names for the phenomenon that Spinoza referred to-including, since colonisation, the name "God", which is problematic for a number of Māori because of its relationship with Judaeo-Christianity. But it is here that I really want to focus for this paper, because Spinoza wants us to conceive of primordial substance as giving rise to all things. It is precisely Spinoza's sustained emphasis on God as it exists as things in the world that sparks my own interest. Nature is a whole, existing necessarily, which for Spinoza means that it exists without cause. This proposition opens up a complication for Māori thought in the sense that its translation into the Māori context has major consequences. One immediately relevant entity here is Papatūānuku. It is currently entitized to mean Earth Mother, and this entitizing in itself is not a problem for Spinoza, but it becomes a detrimental concept if we think of Papatūānuku as material in the conventional, physical sense. Papatūānuku is matter itself, but, interestingly for the Māori thinker, it can be interpreted as being "beyond cause". The term "matter", having taken on coat-upon-coat of static property and cause, is inappropriate for what we are discussing. Māori theologian and philosopher Māori Marsden (2003: 22) has noted-with different terminology to that of Spinoza's-that Papatūānuku is endless and uncaused. While Papatūānuku or primordial substance takes up breadth and length, this does not rule out Papatūānuku as an existential ground. However, these two attributes are the same in Māori philosophy.

When I envisage this primordiality, I can only approximate it through thinking about myself as a colonised being alongside it; I can't think of it from an entirely traditional Māori perspective. I can make declarations about it, but it would be disingenuous of me not to acknowledge that I am making those declarations through an outline of cause and effect, and a drive to represent the properties of a thing. Spinoza was aware of this danger. Thus, I envisage myself as a colonised speaker on this theme, talking about Papatūānuku as if I am separate from it. This is a colonised undertaking because Māori prior to colonisation would have been much more focused than I can be on actually presenting infinitude through various mediums, rather than being encouraged to represent it, despite my attempts at presenting Papatūānuku as a decolonising project. Strangely, when I try to imagine the full extent of Papatūānuku, I can only envisage it as a sort of formal patterning, where I am implicated as a thing emerging from it even as I make those declarations on it. Perhaps, then, Papatūānuku is a very real form within my thinking. Where Spinoza would say that the attributes thought and extension are to be considered distinct yet the same (in that they are constituted by the infinite substance-see Fullerton, 1894: 14), Māori could argue that whakaaro-which is loosely translated as "thought" - is in itself simultaneously extension. Their similitude is unsurprising; whakaaro is as much material as conceptual (Mika, 2017: 13), in much the same way as Papatūānuku is. In our genealogy, whakaaro is noted as an entity and thus is an extensional embodiment of Papatūānuku.

It is useful at this point to indicate a huge difference between "to think" and the Māori term for that English verb (or for "thought" if we are using the noun). "Whakaaro" might be translated as "to think", but it points to an entirely different world. Admittedly, it is probably the closest term in Māori that conveys 
something of "to think". But it comprises the two words "whaka" and "aro", which do not meet up with "to think" on their own. There is a difference in "density" between "whakaaro" and "to think". "Aro" is a material orientation towards other things in the world, in the sense that all things are one (Mika, 2014a). It is often taken to mean the field in front of the self that can sense things, but it also indicates a mutual engagement between things such that they are unified consistent with such terms as "ako" (teach/learn) (Thrupp \& Mika, 2012: 210). In short, they are manifestations of the primordial substance. This eternal engagement with each other derives from the prefix "whaka". There are a number of interesting possibilities with this prefix, because it is nearly always defined as "to cause". Of course, because we live in a highly teleological age, the assumption is that "to cause" is of a particular type which does not correspond with Māori thought. But this mutual engagement has always already occurred, not because of Papatūānuku but through its embeddedness within all things in the world. To that extent, "whaka” closely resembles Spinoza's immanent cause, which advocates for a view of God as without cause, completely within the world. Of course, this is incredibly difficult to describe using academic terminology, as Novalis and his group, for example, were also aware, which is why they used poetic discourse-it retains the unity of things in the world as a focus.

To try to describe the extremely dense nature of Māori causation, which runs counter to everything colonised discourse tells us, we have to give long, drawnout explanations. Amazingly, though, just that one Māori term is enough to convey this complexity, especially if there is a background critique going on that tries to prevail against its colonised and commonsense definition. Perhaps the most frequently used concept that uses the term "whaka" is "whakapapa". "Whakapapa" is nearly always translated as "genealogy", but just as its counterpart "whakaaro" is something different to the English "to think", so "whakapapa" differs from "genealogy". The reader will see, again, that I am less concerned about the meaning given to a term and more with how it sits as a materiality. "Whakapapa" may well include something of "genealogy, but it is far more oriented towards the All than that. It may instead refer to a phenomenon of infinite substance-manifestations. By that I mean whakapapa is the always-already immersion within the infinite substance (see for example Mika, 2017: 13). All things in a Māori worldview have a genealogy-plus-All; all things are manifestations of a togetherness with Papatūānuku. Indeed the "Papa" in whakapapa is an abbreviation of Papatūanuku. Primordiality is thus fundamental to whakapapa. Rather than being a first designator of other, subsequent entities, Papatūānuku is both first and simultaneous. Conversely, given that all things share in her, all things are first and simultaneous (Mika, 2017: 13). Senghor argues similarly that African indigenous philosophy emphasises the materiality of things as indications of the All (2010: 479). In Māori thought, as I have noted, this All, in turn, comprises its things. This apparently-first-but-simultaneous phenomenon reflects a Māori view of time as collapsed and presents a difficulty for anyone who wants to adequately express te reo Māori, with its spiritual and material impact, in modern academic convention (for example, see Mika \& Southey, 2018: 6).

I have argued elsewhere that, in Māori thought, this phenomenon of the self's encounter with the limits of a thing because of its relationship with Papatūannuku can be conceived through the term "ira" (Mika, 2015: 93-94). Commonly defined as "essence", "ira", I argued, deals with the unknowability of things in the world 
but, more importantly, is the drive of the self to come to terms with his or her limits of knowledge in relation to it. It is "over there!"-a meaning of "ira", used in an exclamatory sense. With "ira", we strive to speculate on the unknowability of a thing due to the fact it is part of the All, thus ensuring it remains mysterious. Spinoza's notion of conatus, which depicts the pursuit of a thing for its further perfection in relation to God, is somewhat different, despite also reading broadly from the notion of "essence". Especially in colonised times, the retention of mystery and uncertainty is important as an existential characteristic of the Māori self. Papatūanuku brings to the fore the uncertainty of the self's relationship with the thing, which is in fact an embodiment of Papatūānuku. One uncertain thing encounters another. Our genetic relationship-"ira" is often glossed as "gene"-is less important in "ira" than that passion of the human self to run up against the limits of his or her knowledge. It is at this point that "ira" diverges from conatus, for although "ira" can "take [...] pleasure in its own enhanced power of understanding" (Ravven, 2013: 234), the mind itself is bound up in its inability to know a thing-keeping in mind that the thing is unknowable due to its immediate embodiment of the All.

This raises the question of Spinoza's denouncement of "foolish wonder", referred to earlier. Spinoza believes that a transcendent God encourages a silly belief, where we are at the whim of miracles and so forth. Incidentally, here is a marked difference between Spinoza and Novalis-Novalis paradoxically advocates for a primordial substance that the world is within, but also transcends. But in Māori philosophising, there may be less of a difference between what may be thought of as a Spinozan "foolish wonder" and its more valid relative, affective wonder. The term for wonder in Māori, "mìharo", connotes both at once: a sense of inertia in the face of something magnificent that simultaneously constitutes the self (and hence provides the movement as a necessary component of affective wonder). Wonder-which is the enactment of the thoroughly constitutive All, to the extent that we are helpless in the face of it-is a crucial aspect of our philosophy. It brings us to realise, for instance, that even though we might have proven God exists through steps in our reasoning, as Spinoza reputedly did, that very phenomenon of reason takes place within the phenomena of "drive" or "predisposition", which are in turn manifestations of the All, as all things are. We are acting within provability's domain. We are forced to discern and to switch off emotion; however, that tinge never disappears. The reasoning we have employed is dependent on infinite contingencies, and I reiterate here that Māori philosophy may be more intent on exploring the speculative outcomes of not knowing in relation to grasping any particular contingency at any point than dominant Western philosophy. It then happens that these contingencies constitute the proven phenomenon, to the extent that our means of proving it-reason-is not particularly reasonable or reasoned. The drives we have sought to extinguish in favour of the intellect-emotion, the spiritual, the recognition of the non-human worlds and so on-persist throughout the method and outcome of reason.

The drive towards nature or primordial substance that "whakapapa" ordains comes to the fore in the way we are predisposed towards our relations-other things in the world besides humans-which is encapsulated in both "whakaaro" and the exclamatory drive of "ira". This intuitive orientation, as I have already outlined, is not a definitive one. For Māori, as for Spinoza's affect, it calls for that first non-rational intuition that Māori often talk about, even though they may 
perhaps go on to discuss rationally. It is always implicated with the colonising lens, the grappling with which, I suggest, also brings about a weird kind of satisfaction of mind because it adds to the uncertainty of knowledge generally. If I encounter a phenomenon-for instance, "mountain", in itself it is beyond my complete knowing because it is pervaded by the All. Here, we diverge from Spinoza because for him the mountain cannot be infused with the All; it is instead an aspect of the All. For Spinoza there must be a distinction between substance and its modes because, otherwise, the mountain would be the All, and the All would be the mountain (and thus wouldn't be the All any longer). Wonder for Spinoza depends on difference between, say, myself and the mountain, where for Māori the "mīharo" I noted before constitutes myself as the other thing in its totality, together with its (and my) constitution by the All. Thus, as Māori we can represent the mountain using a quick and easy template of "mountain-ness", but that is different to grasping the entirety of the mountain. When I add colonisation to the mix, then the calling of the phenomenon a "mountain" rather than "maunga", the fact (perhaps) of its European name, its manifestation within a colonised soil, and so on, are all complicating features to knowing it in its entirety. Colonisation has an element of thrill to it because it imposes further limits on what is already beyond us, but it also further inclines us towards or within the object or idea being considered.

\section{Conclusion}

For Māori, passions and agency may be the same. They are both constitutive of and by Papatūānuku, no one more than the other. Because Māori have always thought that things outside us are in fact part of us, then what goes on without, happens within and vice versa. This is illustrated in Raerino's (1999: 73) belief that one never talks about a mountain as if separate, but as if he or she were in direct relation with it. It is also partially illustrated in the recent decision (see for instance Davison, 2017) where the Whanganui river was given personhood in law and in the unity acknowledged between that river and the iwi (tribal) members. Whilst it is easy to state this, it is much harder to find the language to reflect its integrity and gravitas. I alluded to the Early German Romantic poet and philosopher, Novalis, earlier on, and I conclude by declaring one of the many similarities between him and Spinoza. I am acutely aware that they held the metaphysical in not just their propositions about the world but also within the way they framed those propositions. I suspect that there is much to be learned from their example for those Pākehā who become squeamish at the mention of metaphysics. Māori have not yet succumbed to making the topic of metaphysics off-limits-but the challenge lies for all of us in retaining it in our academic writing. There are several reasons for this abandonment which are outside the pragmatics of this paper but I can summarise by noting that Spinoza does not have to limit our own thinking on the way in which an object can be perceived in relation to the whole. Instead, he can act with other provocations to stoke the fires of thought that encourage Māori to consider what is basically imponderable. It is this process, I suggest, that Spinoza brings to the fore and challenges us with; the Spinozan retention of the metaphysical is itself a manifestation of Papatūanuku, and the importance of that, Spinozan or otherwise, should thus take precedence in Māori thought and expression. 


\section{REFERENCES}

Beiser, F. (2002). German idealism: The struggle against subjectivism, 1781-1801. Cambridge, MA: Harvard University Press.

Davison, I. (2017, March 15). Whanganui River given legal status of a person under unique Treaty of Waitangi settlement. New Zealand Herald. Retrieved from https://www.nzherald. co.nz/whanganui-chronicle/ news/whanganui-river-givenlegal-status-of-a-person-underunique-treaty-of-waitangisettlement/JL3QKSWVZPA 7XW6EN33GKU4JJ4/

Fullerton, G. (1894). Brief exposition of Spinoza's system. In G. Fullerton (Ed.), The philosophy of Spinoza: As contained in the first, second, and fifth parts of the 'Ethics' and in extracts from the third and fourth (pp. 13-22). New York, NY: Henry Hold and Co.

Marsden, M. (2003). The woven universe: Selected writings of Rev. Māori Marsden. Otaki, New Zealand: Estate of Rev. Māori Marsden.

Mika, C. (2013). Western 'sentences that push' as an Indigenous method for thinking. In A. Engels-Schwarzpaul \& M. Peters (Eds.). Of other thoughts: Non-traditional ways to the doctorate. A guidebook for candidates and supervisors (pp. 23-26). Rotterdam, Netherlands: Sense Publishers.
Mika, C. (2014a). The enowning of thought and whakapapa: Heidegger's fourfold. Review of Contemporary Philosophy, 13, 48-60.

Mika, C. (2014b). Māori thinking with a dead white male: Philosophizing in the realm of Novalis. Knowledge Cultures, 2(1), 23-39.

Mika, C. (2015). The co-existence of self and thing through "ira": A Māori phenomenology. Journal of Aesthetics and Phenomenology, 2(1), 93-112.

Mika, C. (2017). A term's irruption and a possibility for response: A Māori glance at "epistemology". In E. McKinley \& L. Smith (Eds.), Handbook of Indigenous Educatio (pp. 1-19). Dordrecht, Netherlands: Springer. doi: 10.1007/978-981-101839-8_20-1.

Raerino, N. (1999). "Pure” and "Karakia" as a window to Māori epistemology: Koi rō pure me karakia e oke ana (Unpublished thesis, The University of Auckland). Retrieved from http:// hdl.handle.net/2292/2961

Ravven, $\mathrm{H}$. (2013). The self beyond itself: An alternative history of ethics, the new brain sciences, and the myth of free will. New York, NY: The New Press.

Senghor, L. (2010). Negritude: A humanism of the twentieth century. In R. Grinker, S.

Lubkemann \& C. Steiner (Eds.), Perspectives on Africa: A reader in culture, history, and representation (pp. 477-483). Malden, MA: Wiley-Blackwell.

Spinoza, B. (1894). Of God. In G. Fullerton (Ed.), The philosophy of Spinoza: As contained in the first, second, and fifth parts of the 'Ethics' and in extracts from the third and fourth (pp. 25-73). New York, NY: Henry Hold and Co.

Thrupp, M. \& Mika, C. (2012). The politics of teacher development for an indigenous people: Colonising assumptions within Māori education in Aotearoa, New Zealand. In C. Day (Ed.), The Routledge international handbook of teacher and school development (pp. 204-213). London, England: Routledge. 